\title{
CORONAVIRUS Y GRANJAS INDUSTRIALES. NUGGETS Y MURCIÉLAGOS: CÓMO COCINAMOS LAS PANDEMIAS DE HOY*
}

Soledad Barruti

" DOI: https://doi.org/10.18601/01245996.v23n44.04. Recepción: 15-052020, aceptación: 27-11-2020. Sugerencia de citación: Barruti, S. (2021). Coronavirus y granjas industriales. Nuggets y murciélagos: cómo cocinamos las pandemias de hoy. Revista de Economía Institucional, 23(44), 71-79. E1 escrito original fue ilustrado por Rocío Galarza, diseñadora gráfica graduada en la Universidad de Buenos Aires.

a Periodista y escritora. Directora de Bocado, red de periodismo en defensa de nuestros sistemas alimentarios, [info@bocado.lat]. 


\section{Coronavirus y granjas industriales. Nuggets y murciélagos: cómo cocinamos las pandemias de hoy}

Resumen Se atienden las consecuencias de la COVID-19, pero no las causas que provocaron 200 nuevas enfermedades como la del coronavirus en las tres últimas décadas. Ninguna fue producto de la mala suerte. La relación depredadora con la naturaleza, la crueldad y la insalubridad en las granjas industriales, la pérdida de potencia de los antibióticos y la ambición empresarial (en cuarentena se destruyeron 2200 hectáreas de bosques en la Argentina) hacen de nuestro mundo un lugar bizarro y cada vez más peligroso.

Palabras clave: Coronavirus, granjas industriales; JEL: H50, H53

\section{Coronavirus and factory farms. Nuggets and bats: How we cook today's pandemics}

Abstract The consequences of COVID-19 are addressed, but not the causes that caused 200 new diseases such as coronavirus in the last three decades. None were the product of bad luck. The predatory relationship with nature, the cruelty and unhealthiness in factory farms, the loss of The power of antibiotics and business ambition $(2,200$ hectares of forests were destroyed in argentina in quarantine) make our world a bizarre and increasingly dangerous place.

Keywords: Coronavirus, factory farms; JEL: H50, H53

\section{Coronavírus e fazendas industriais. Pepitas e morcegos: como preparamos as pandemias de hoje}

Resumo As consequências do COVID-19 são abordadas, mas não as causas que causaram 200 novas doenças, como o coronavírus, nas últimas três décadas. Nenhum foi produto de má sorte. A relação predatória com a natureza, a crueldade e a insalubridade nas fazendas industriais, a perda de $\mathrm{O}$ poder dos antibióticos e a ambição dos negócios (2.200 hectares de florestas foram destruídos na Argentina em quarentena) tornam nosso mundo um lugar bizarro e cada vez mais perigoso.

Palavras-chave: Coronavírus, fazendas industriais; JEL: H50, H53 
"Sabemos que otra pandemia será inevitable. Está llegando. Y también sabemos que cuando esto pase no vamos a contar con suficientes drogas, ni con vacunas, ni trabajadores de la salud, ni capacidad hospitalaria”, dijo en 2004 Lee Jong-wook, entonces director de la Organización Mundial de la Salud. El discurso tuvo lugar mientras el planeta intentaba recuperarse del susto que surgió con la gripe aviar que brotó en Hong Kong en 2003. E1 médico advirtió allí algo que era muy difícil de escuchar: que un brote peor podría ocurrir en cualquier momento.

En 2009, por ejemplo. Cuando otro virus saltó de un cerdo para convertirse en la Gripe A que se disparó de México a todo el mundo. O en 2012 cuando de los camellos de Arabia Saudita brotó el MERS que alcanzó contagios en 27 países.

"A los misiles no, a los virus es a lo que hay que temer", dijo Bill Gates en la Ted Talk que dio en 2015, luego de que en 2014 el Ébola rompiera los límites del murciélago para convertirse en pesadilla de los humanos.

"Es una emergencia", "Hay que organizar los preparativos", "Necesitamos controlar los virus": los documentos oficiales de las distintas agencias de Naciones Unidas, organizaciones globales como la Fundación Gates y varios gobiernos están repletos de advertencias similares. Pero nada pudo hacerse para evitar la COVID-19. Tal vez porque en ninguno de esos espacios de poder se nombró con claridad y contundencia el principal disparador de estas enfermedades: la relación abusiva y depredadora que establecimos con la naturaleza en general y con los otros animales en particular.

Vacas, cerdos, gallinas, murciélagos, no importa de qué animal se trate. Si no los extinguimos mientras destruimos sus hábitats, los enjaulamos, hacinamos, mutilamos, traficamos, engordamos, medicamos y deformamos para aumentar su productividad. Forzamos sus cuerpos y anulamos sus instintos como si fueran cosas, con prácticas que están lejos de ser marginales: se enseñan en la universidad, se subrayan en congresos empresariales y se ensayan con miles de millones mientras los manipulan, crían y matan.

Nunca paseé en camello ni visité los mercados asiáticos donde monos, pájaros y armadillos se ofrecen vivos en cajas diminutas, pero sí recorrí una buena cantidad de granjas industriales en América Latina, de donde sale la comida que luego se nos hace tanto menos exótica y cruel, más civilizada y segura. $\mathrm{Y}$ ahí aprendí que la diferencia entre lo 
que se ofrece en Wuhan y lo que rellena muchas de las góndolas de supermercados como Carrefour, en cuestiones como ética, empatía y salud pública es imaginaria.

Las pestes no son una novedad, pero se están precipitando: en los últimos 30 años surgieron 200 enfermedades infecciosas zoonóticas, y ninguna es producto de la mala suerte.

Visité a Rosalía de Barón en 2011 mientras hacía la investigación que terminaría en Malcomidos. Ella - una simple productora de huevos de Crespo, en Entre Ríos- lo sabía perfectamente: su gallinero era una mina de oro con una única debilidad: podía desatar la peste.

"Desde que soy así ando entre los huevos", me dijo y bajó la mano al suelo mientras entrábamos al galpón que encerraba unas $40 \mathrm{mil}$ gallinas en plena producción. Rosalía era una mujer fuerte de poco más de 40 años con ojos celeste Rusia, pelo rubio gastado y el orgullo de llevar adelante un negocio próspero: 80 cajones de huevos diarios de la mejor calidad. Unas diez veces más de lo que generaba su misma granja cuando ella era chica, en el mismo espacio. ¿El truco? La concentración automatizada. El gallinero moderno no tiene tierra ni arbustos ni sol sino jaulas de unos 40 centímetros donde las gallinas viven cuatro años amontonadas de a diez. Las jaulas están unas sobre otras y unas junto a otras haciendo del lugar un laberinto tapizado íntegramente de plumas y picos y patas difíciles de interpretar a simple vista.

Intenten imaginarlo: diez gallinas amuchadas en un espacio donde ni de a una entrarían cómodas, sin lugar para batir sus alas, echarse, darse vuelta. Sin modo de satisfacer ninguno de sus requerimientos biológicos más que dar un huevo diario.

Hacinadas, las gallinas no pueden hacer más que escalarse unas a otras, enredarse, y sacar la cabeza por los barrotes hasta llagarse el cuello, dejándolo en carne viva. Es tan estresante eso que viven, que a las semanas se vuelven caníbales. Para evitar que se coman entre sí, a los pocos días de vida les amputan la punta de los picos, que luego les crecen planos, como si se hubieran tenido un fuerte choque contra una pared.

Que no se maten mientras sostienen la producción al máximo: ese es el objetivo y para cumplirlo hay intervenciones así: mutilaciones, manejo de luces, sonidos constantes, varios días de hambre y sed. Replume forzoso se llama ese último: 15 o 20 días sin alimento ni 
agua. Las gallinas agonizan como juguete al que se le está terminando la batería: consumidas, echadas una sobre la otra, con los ojos secos, los picos abiertos, emitiendo un jadeo apenas audible. Se espera que de esa hambruna inducida sobrevivan solo las fuertes. A esas, se les renueva la ración y al otro día, magia: un nuevo huevo, el cacareo infernal; para quien pueda sentirlo también el miedo, la carne rota, el olor a muerte en vida.

Visitar granjas industriales por primera vez tiene algo monstruoso: ni los ojos, ni los pulmones, ni la mente están preparados para aprehender lo que ahí sucede. Lo que se ve, lo que los cuidadores de animales - tan normales, como una vecina, un tío, una dentista- cuentan. La información llega por etapas: la sistematización de la crueldad, la negación del dolor que es evidente y la única fundamentación a todo eso en las leyes propias del mundo del dinero, tan absurdas, tan perversas, se van convirtiendo sin querer en una íntima resistencia: buscás que no te afecte.

Adorno decía que había que mirar a los mataderos y decir son solo animales para entender el origen de Auschwitz.

Es difícil ante estos criaderos y su naturalización decir el origen de qué son.

Tal vez sea demasiado.

Rosalía me explicó lo que sabía y me mostró lo que le resultaba fascinante: "Trabajo solo dos horas por día, el resto se hace solo", me dijo y apretó un botón que hizo que el gallinero empezara a moverse. Por debajo de las jaulas, unas cintas transportaron huevos hacia el lugar donde serían medidos y empaquetados. Otras cintas transportaban el guano que terminaría enterrado en una fosa a unos metros del galpón. En la misma coreografía maquinal se rellenaron bebederos y comederos, con el maíz, las vitaminas, el colorante para las yemas naranjas que hoy pide el mercado. La precisión fabril parecía mostrar que todo estaba bajo control. Los materiales fríos y duros revestían de asepsia todo el proceso, pese a lo evidente: la mierda, los fluidos, los ojos llenos de pústulas, las plumas volando.

- "Sin embargo", me dijo Rosalía, "nada es tan fácil”.

La granja tenía un peligro acechante.

- ¿Cuál?, le pregunté.

- Las enfermedades. Las gallinas parecen fuertes pero una podría enfermarse y sería el fin, me dijo.

Pensé en el replume forzado: si resisten a eso débiles no son, me dije. Pero enseguida aprendí que no. Las gallinas no sobreviven a una gripe. 
La influenza es el talón su Aquiles.

Tener a las enfermedades bajo control en un gallinero es un asunto difícil. Requiere generar condiciones que desmaterialicen esta realidad rotunda: decenas de miles de animales hacinados, respirando pegados entre sí, cagando juntos, unos sobre otros, estresados, dolientes. Requiere limpieza permanente. Requiere medicación: antibióticos y antivirales. Y requiere mantener al resto de la naturaleza a raya: las aves silvestres que portan los virus que podrían hacer de esa concentración de animales extenuados, focos de contagio incontenibles.

Antes de instalar el gallinero Rosalía tenía tres faisanes y dos pavos reales correteando por la granja. Pero cuando cerró la última jaula, echó a andar el mecanismo e hizo cuentas, metió a sus pájaros en un cuartito del que ya no iban a salir más. Luego se encargó de las garzas y los patos que un tiempo atrás eran una belleza de mirar: compró un rifle y cuando caía la tarde empezó a disparar al cielo esperando ahuyentarlos. "Si alguno se metiera acá adentro perdería todo, sería un desastre", me dijo.

A sus vecinos ya les había pasado. Un gallinero contagiado deviene en una masacre. Sacrificio sanitario de todos los animales, eso exige la legislación siguiendo el protocolo que dicta un acuerdo global. Solo en Asia en los últimos años tuvieron que matar 200 millones de aves de corral para evitar que se propagaran virus entre otros animales domésticos. Pero sobre todo para evitar que los virus mutaran hacia versiones de sí mismos que pudieran hospedarse en humanos, enfermarnos, colapsar los sistemas de salud y, a unos cuantos, matarnos.

En 1918 la gripe española infectó a media humanidad y mató entre 50 y 100 millones de personas (los números varían según cómo se estimen los registros de algunos países). Si bien el origen sigue siendo motivo de investigaciones, el más probable apunta a las granjas de pollos que empezaban a reproducirse en Kansas. O sea a personas intensificando la producción y rompiendo la sana distancia entre reinos -todos con sus microorganismos particulares- para crear un mundo nuevo bizarro y cada vez más peligroso.

"Todos los virus infecciosos que nos aquejan pueden relacionarse de algún modo con las granjas industriales", dice Rob Wallace, biólogo y autor del libro Bigfarms, bigflues.

Se trata de una amenaza que se multiplica exponencialmente: la cantidad de animales que se crían para comer crece desde hace déca- 
das casi al doble de rápido que la población humana. Ahora mismo hay unos 70 mil millones de animales encerrados como las gallinas de Rosalía. Aves, vacas, cerdos separados por el producto que se les extraerá (carne, huevos, leche), en establecimientos donde comparten raza, edad y sistema. Y eso para la naturaleza -cuya ley más importante es el equilibrio que logra en la diversidad-, quiere decir una plaga gigante. Una atracción inevitable para otros animales. Un festín para los gérmenes. Un experimento permanente de mutaciones y contagios cada día más extremo.

Hay diez animales domésticos por persona. Elijan el que quieran ser. Gallinas como las de Rosalía. Pollos que se engordan en galpones de a 50 mil el doble de rápido que hace 50 años. Terneros que crecen en corrales apretados, entre bosta, orina y barro, comiendo cosas para las que no están preparados: granos, celulosa y (dicen que ya no) sangre de otros animales. Vacas preñadas sin descanso con ubres de 40 litros de leche (cuatro veces más que hace 30 años), también acorraladas. Cerdos hacinados que nacen de cerdas que viven toda su vida entre jaulas del tamaño de sus cuerpos aprisionados.

En cualquier caso será igual: vivirán con los ojos rojos, lacerados e hinchados por el cansancio, respirando aire viciado, manteniendo cierta rebeldía y, salvo una desgracia, nunca lo suficientemente enfermos.

$\mathrm{La}$ industria logró generar para las granjas industriales chalecos químicos que contienen o disimulan las expresiones esperables de vivir en esas condiciones: acidez, alergias, infartos, infecciones de las más variadas. En un estudio que hizo el investigador Rafael Lajmanovich en Argentina sobre galpones de pollo encontró restos de todo tipo de drogas, desde antivirales, hasta clonazepam. Y sobre todo antibióticos.

Los antibióticos en la cría de pollos tiene dos usos: preservar la salud y promover el engorde. En la de cerdos, lo mismo. Diezmar el microbioma intestinal de los animales enlentece su metabolismo, lo que los ayuda a ganar más peso en menos tiempo. En los tambos el uso es distinto: es tanta la exigencia de esas vacas cada vez más rellenas de leche que las infecciones mamarias conocidas como mastitis en algunos lugares parecen inerradicables y no hay otra salida que retirar a los animales de producción y ponerlas en tratamiento.

Así, el 80 por ciento de los antibióticos que se producen en el mundo terminan en granjas industriales, azuzando otra pandemia que deberíamos empezar a registrar antes de que rija nuestras vidas $y$, otra vez, nos colapse. Porque, sumado al mal uso que se hace en salud humana, los antibióticos que marcaron un antes y un después en nuestra esperanza de vida, están perdiendo su efectividad. La re- 
sistencia bacteriana provoca hoy 700 mil muertes por año, y de seguir así se espera que el número se eleve a 10 millones para 2050.

Los antibióticos, que se dan en microdosis diarias o en tratamientos cada vez más recurrentes, alimentan a las bacterias que alojan esos animales, quedan en su carne que luego se vende al público, en la tierra en la que terminan sus deposiciones, en el agua en donde todo fluye, también nuestras peores ideas.

Los antibióticos cumplen su propósito comercial -los animales engordan y aguantan- pero también hacen que las bacterias muten para no morir. Al igual que los virus, salen de los criaderos fortalecidas en busca de nuevos huéspedes, los colonizan, y los hacen morir de cosas de las que no hubiéramos muerto si las bacterias no hubieran sido alimentadas con la cura que por eso ya no nos sirve. Tuberculosis, infección urinaria, sepsis: el acta de defunción puede completarse con cualquiera de esas cosas, aunque sería más preciso poner: daño colateral provocado por un sistema demente.

Antropoceno. Así se llama nuestro momento actual, en el que logramos lo que los asteroides: imprimir nuestra huella en las capas geológicas del planeta. Radiación aumentada, toneladas de plástico y huesos de pollo. Si un explorador del futuro quisiera saber qué éramos encontraría que, sin restricciones religiosas y a un precio más barato que el resto, comimos pollos de a tantos miles de millones que los volvimos un registro fósil más importante que el de las majestuosas ballenas y los leones (probablemente extintos para entonces).

Porque, sí: ésta también es la era de la sexta extinción.

Y del calentamiento global.

Y de las pandemias evitables.

Con el sistema alimentario como punta de lanza, nos arrojamos a cambiar el mundo para peor, de lo visible a lo invisible. Nos volvimos la especie en peligro de extinguirlo todo, en un proceso que no conoce cuarentenas.

"Los desmontes no se detienen. Mientras la mayoría de los ciudadanos nos quedamos en casa, la ambición de algunos empresarios rurales no tiene freno. Las topadoras avanzan arrasando con impunidad nuestros últimos bosques nativos", advirtió hace unos días Hernán Giardini, que coordina la campaña de bosques de Greenpeace, con un seguimiento permanente sobre la deforestación en Argentina. En los últimos diez días de marzo destruyeron casi 2.200 hectáreas de 
árboles, arbustos, animales silvestres que tardaron miles de años en crear ese ecosistema.

El asunto también es global: por minuto, por día, los 365 días del año, desaparecen 40 canchas de fútbol de naturaleza. ¿Qué ocupa su lugar? Vacas y monocultivos de granos de soja y maíz para alimentar a otra vacas en corrales, a cerdos, a gallinas, a pollos. Un tercio de la tierra está cultivada por comida para animales de granja industrial. Dos o tres producciones de plantas para cuatro o cinco tipos de animales.

La biodiversidad es el único control de plagas que existe. Una barrera de amortiguamiento. Una red que descosimos dejándonos a la intemperie y entre zumbidos de mosquitos con malaria, dengue, fiebre amarilla, zika. De vinchucas con Chagas. De roedores con hantavirus. De ciervos con Lyme. En Amazonas, la cantidad de mordiscos de murciélagos aumentó nueve veces en las áreas de deforestación en los últimos años.

Y así llegamos a los murciélagos y armadillos.

Los animales silvestres, sin lugar donde vivir, con la naturaleza jibarizada, se acercan peligrosamente entre sí. Y eventualmente se acercan a los animales hacinados en granjas industriales. $\mathrm{O}$ se convierten en ejemplares que se venden en los mercados húmedos de animales vivos. Donde los virus se expresan, y mutan. $Y$ las bacterias, lo mismo. Y en las ciudades del mundo los hoteles, los teatros, las escuelas se vuelven hospitales. Y la vida cotidiana se detiene. Y parece que el mundo es otro. Pero no. Ahí están abiertos los supermercados donde hacemos filas eternas para hacernos de cosas -nuggets, huevos, un yogurcito-, con las que seguimos cocinando las pandemias que luego nos parecerán inevitables. 